УДК 621.565

'А.А. Вассерман, доктор техн. наук; ${ }^{2}$ А.Г. Слынько, кандидат техн. наук; ${ }^{3}$ О.А. Россомаха, аспирант Одесский национальный морской университет, ул. Мечникова, 34, г.Одесса, Украина, 65029

e-mail:1avas@paco.net; ${ }^{2} a s g \_37 @ u k r . n e t$

ORCID:'http//orcid.org/0000-0001-8147-8417; http://orcid.org/0000-0002-5310-4335;

${ }^{3}$ orcid.org/0000-0002-0230-9453

\title{
ПОВЫШЕНИЕ ЭКОНОМИЧНОСТИ УСТАНОВОК РЕКОНАЕНСАЦИИ ПАРА СЖИЖЕННЫХ ГАЗОВ
}

\begin{abstract}
Предлагается в цииле каскадных установок реконденсации пара сжиженных газов перед каждым компрессором регенеративно перегревать пар рабочего вещества до соответствующей температуры конденсации, а затем изотермически сжимать его до давления конденсации. Это уменьшает необходимую мощность установки, снижает температуру пара после компрессора и позволяет глубже охлаждать рабочее вещество перед дросселированием. Благодаря этому увеличивается холодильный коэффициент установки и улучшаются условия работы компрессоров. Модернизация циикла каскадной установки реконденсащии для газовоза грузовместимостью 75000 м $^{3}$ уменьшит её эффективную мощность на $22 \%$. Это позволит экономить при перевозке этилена до 5400 кВти, а при перевозке этана - до 3100 кВтч электроэнергии в сутки.

Ключевые слова: Сжиженные газы. Установки реконденсации. Регенеративный теплообмен. Адиабатное и изотермическое сжатие. Удельная массовая холодопроизводительность. Холодильный коэффициент.
\end{abstract}

\section{BBEAEHИE}

Основным недостатком газовозов, перевозящих сжиженные газы (СГ) при давлении, близком к атмосферному, является большая затрата энергии на реконденсацию пара, образующегося при транспортировке СГ вследствие неизбежных теплопритоков в грузовые танки. Поэтому усилия, направленные на снижение этой затраты, являются актуальными.

Уменьшить потребление энергии в обычной одноступенчатой холодильной установке позволяет замена адиабатного сжатия хладагента изотермическим. В работе [1] на основании теоретического анализа и расчётов для 10-ти хладагентов показано, что холодильный цикл с изотермическим сжатием хладагента имеет существенные преимущества перед циклом с адиабатным сжатием.

В настоящей работе на примере перевозки сжиженных этилена и этана показана возможность повышения экономичности работы каскадных установок реконденсации путём аналогичной замены наиболее энергетически затратных адиабатных процессов сжатия пара рабочих веществ в этих установках изотермическими процессами.

\section{2. БАЗОВАЯ И МОАИФИЦИРОВАННАЯ УСТАНОВКИ РЕКОНАЕНСАЦИИ. СОПОСТАВАЕНИЕ ИАЕААИЗИРОВАННЫХ ЦИКАОВ УСТАНОВОК РЕКОНАЕНСАЦИИ}

(c) A.A. Вассерман, А.Г. Сльнько, О.А. Россомаха

DOI: http://dx.doi.org/10.18198/j.ind.gases.2016.0819
При перевозке и хранении сжиженных этилена и этана при давлении, близком к атмосферному, используются каскадные установки реконденсации пара [2]. Принципиальная схема базового варианта такой установки приведена на рис. 1. В нижней ветви каскада размещается двухступенчатая холодильная установки открытого типа с неполным промежуточным охлаждением пара перевозимого сжиженного газа. В верхней ветви каскада также используется двухступенчатая холодильная установка с неполным промежуточным охлаждением, работающая на хладагенте $\mathrm{R} 22$. В нижних ступенях каждой ветви каскада применяется регенеративный теплообмен между жидкостью и паром.

На принципиальной схеме указаны не только элементы холодильной установки, но и положение точек, соответствующих состояниям сжиженного газа и R22, отмеченным на холодильном цикле установки (рис. 2). Схема и цикл выполнены двухцветными для отличия верхней ветви каскада от нижней.

Анализируя схему, отметим, что в вентиле II дросселируется жидкость, получаемая при реконденсации пара перевозимого СГ, при её возвращении в танк. В регенеративном теплообменнике III переохлаждается указанная жидкость и перегреваются пары СГ, образующиеся в танке. В промсосуде IV происходит разделение жидкости и пара после дросселирования СГ в первом дроссельном вентиле V. В конденсаторе-испарителе VI охлаждается и реконденсируется пар СГ и кипит хладагент R22. Во втором дроссельном вентиле 